\title{
PENGEMBANGAN MODUL FISIKA BERBASIS PROBLEM BASED LEARNING PADA MATERI FLUIDA UNTUK SISWA CERDAS ISTIMEWA-BERBAKAT ISTIMEWA
}

\author{
Mukhayyarotin Niswati Rodliyatul Jauhariyah ${ }^{1}$, Sarwanto $^{2}$, Suparmi ${ }^{3}$ \\ ${ }^{1}$ Program Studi Pendidikan Sains Program Pascasarjana Universitas Sebelas Maret \\ Surakarta, 57126, Indonesia \\ mukhayyarotin_87@yahoo.com \\ ${ }^{2}$ Program Studi Pendidikan Sains Program Pascasarjana Universitas Sebelas Maret \\ Surakarta, 57126, Indonesia \\ sar1to@yahoo.com \\ ${ }^{3}$ Program Studi Pendidikan Sains Program Pascasarjana Universitas Sebelas Maret \\ Surakarta, 57126, Indonesia \\ suparmiuns@gmail.com
}

\begin{abstract}
Abstrak
Penelitian ini bertujuan untuk mendesain dan mengembangkan modul Fisika berbasis Problem Based Learning (PBL) untuk siswa Cerdas Istimewa-Berbakat Istimewa (CIBI). Metode penelitian yang digunakan ialah modifikasi Model 4-D yang dikembangkan oleh Thiagarajan, Semmel \& Semmel. Pengembangan modul diawali dengan melakukan analisis kebutuhan siswa dan guru terhadap modul Fisika berbasis PBL untuk siswa CIBI dan mendefinisikan materi ajar yang dikembangkan. Hasil pendefinisian terhadap kurikulum dan karakteristik siswa digunakan untuk mengembangkan modul Fisika berbasis PBL untuk siswa CIBI yang disesuaikan dengan sintaks PBL. Telaah dan validasi dilakukan tiga tahap. Tahap pertama telaah dan validasi dilakukan oleh ahli bahasa dan kegrafisan serta ahli materi. Setelah revisi dilakukan berdasarkan masukan pada tahap pertama, dilakukan telaah dan validasi tahap kedua oleh dosen Fisika yang juga menilai instrumen penelitian lainnya. Setelah revisi terhadap modul pada tahap kedua, dilakukan telaah dan validasi tahap ketiga oleh rekan sejawat (guru Fisika kelas akselerasi) sehingga diperoleh modul akhir yang siap diujicobakan ke siswa. Uji coba penggunaan modul ke siswa melalui desain penelitian posttest-only control design. Hasil penelitian menunjukkan bahwa modul layak digunakan dengan kriteria baik (penilaian dari ahli sebesar 3,22; penilaian dari dosen sebesar 3,45; penilaian dari guru sebesar 3,61 dengan skala maksimum 4). Respon siswa terhadap modul sangat positif. Siswa sangat tertarik dengan penggunaan modul Fisika berbasis PBL dan merasa mudah dalam menggunakannya. Berdasarkan uji statistik, diperoleh hasil bahwa siswa yang menggunakan modul Fisika berbasis PBL memiliki hasil belajar kognitif, afektif, dan psikomotor yang lebih baik daripada siswa yang menggunakan buku di sekolah dalam lingkungan belajar PBL. Artinya, modul Fisika berbasis PBL efektif digunakan untuk meningkatkan hasil belajar kognitif, afektif, dan psikomotor siswa.
\end{abstract}

Kata kunci : Pengembangan Modul Fisika, Problem Based Learning, siswa CIBI.

\section{Pendahuluan}

Konsep dan ide kelas akselerasi berasal dari Direktorat Pendidikan Luar Sekolah, Dirjen Dikdasmen Depdiknas, yang intinya bahwa anak luar biasa baik hiperior (kecerdasan rendah) maupun superior (kecerdasan tinggi) perlu diberi perlakuan yang istimewa. Hal ini mengacu pada UUD 1945 (amandemen) Pasal 31 ayat (1) yang menyebutkan, "Setiap warga negara berhak mendapatkan pendidikan". Selain itu, UU Sisdiknas tahun 2003 Pasal 5 ayat 4 menyebutkan, "Warga negara yang memiliki kecerdasan dan bakat istimewa berhak memperoleh pendidikan khusus". Kondisi tersebut juga diperkuat oleh Permendiknas No. 
70 Tahun 2009 tentang Pendidikan Inklusif bagi peserta didik yang memiliki kelainan dan memiliki potensi kecerdasan dan/atau bakat istimewa. Dalam perkembangan konsep tersebut, anak luar biasa yang superior diakomodasi dalam pendidikan kelas akselerasi. Anak luar biasa superior ini sering disebut juga sebagai anak CIBI.

Siswa CIBI memiliki karakteristik: cepat belajar, memori yang sangat baik, mampu memecahkan masalah dan memiliki kemampuan penalaran, rasa ingin tahu intelektualnya tinggi, kemampuan untuk melihat hubungan, kemampuan untuk mempertahankan konsentrasi, tanggung jawab dan kemandirian dalam bekerja, inisiatif dan memiliki orisinalitas, berpikir fleksibel, jeli dan tanggap terhadap ide-ide baru, mampu berkomunikasi dengan orang dewasa menggunakan cara dewasa, menikmati tantangan intelektual, halus rasa, kadang-kadang memiliki humor aneh (Thomson, 2006). Karakteristik ini tidak muncul secara keseluruhan karena bergantung pada kondisi lingkungan sekolah.

Berdasarkan kondisi kelas akselerasi, ada beberapa siswa CIBI yang mengalami kesulitan dalam belajar. Penyebab kesulitan yang dialami siswa CIBI bersumber dari anak itu sendiri, kurikulum, dan lingkungan belajar (Ahmadi, et al., 2011). Oleh sebab itu, harus ada perubahan kurikulum yang disesuaikan dengan kebutuhan siswa.

Siswa CIBI membutuhkan kedalaman materi kegiatan belajar yang lebih besar dan luas serta peluang perpanjangan kurikulum dalam rangka mengembangkan kemampuan siswa (Thomson, 2006). Oleh karena itu, materi untuk siswa CIBI harus terdiferensiasi (terbedakan) dari siswa kelas reguler. Diferensiasi kurikulum meliputi diferensiasi materi, diferensiasi proses, diferensiasi produk, dan diferensiasi lingkungan belajar (Davis dan Rimm, 1998 cit. Direktorat Pembinaan SLB, 2009). Dengan demikian, materi pembelajaran siswa CIBI harus diekskalasi sesuai dengan kebutuhan siswa, yaitu dengan penggunaan ranah kognitif tingkat tinggi dalam pembelajaran, materi bervariasi dan kompleks, terkait dengan pemecahan masalah nyata dalam kehidupan, memungkinkan penelitian mendalam, dan batasan waktu bersifat fleksibel. Penanaman sikap afektif pun ditingkatkan hingga ranah karakterisasi siswa.
Watters \& Diezmann (2003) memandang bahwa siswa CIBI merupakan kontributor penting menuju masyarakat teknologi pada masa mendatang. Penyediaan dukungan untuk siswa berbakat seringkali kurang. Jarang guru sains memberi peluang kepada siswa berbakat untuk melakukan pengayaan dalam sekolah formal. Pendidikan untuk siswa berbakat di bidang sains memiliki sedikit perhatian meskipun kemajuan besar sedang dirancang untuk masa depan. Oleh sebab itu, perhatian khusus kepada siswa CIBI diperlukan dalam belajar sains.

Proses belajar mengajar yang menjadi unggulan yayasan Amanatul Ummah adalah sistem dauroh. Sistem dauroh merupakan kegiatan review materi dan pengkajian ulang soal-soal pada mata pelajaran tertentu, yaitu mata pelajaran yang diujikan dalam Ujian Nasional (UNAS) dan Seleksi Nasional Masuk Perguruan Tinggi Negeri (SNMPTN). Keunggulan sistem ini adalah siswa dapat terbiasa menghadapi soal-soal dengan standar UNAS. Prinsip mengulang-ulang materi pembelajaran dan soal-soal ini sejalan dengan prinsip behaviorisme. Namun berdasarkan hakikat Fisika, pembelajaran yang dilaksanakan harus memenuhi komponen produk, afektif, dan psikomotor. Jadi, proses pembelajaran tidak hanya mengacu pada ranah kognitif, tetapi seharusnya juga pada ranah afektif dan psikomotor untuk pengembangan keterampilan siswa, terutama di bidang sains.

Bruner cit. Dahar (1989) menyarankan agar siswa belajar melalui partisipasi aktif dengan konsep-konsep dan prinsip-prinsip untuk memperoleh pengalaman dan melakukan eksperimen-eksperimen yang mengizinkan siswa untuk menemukan prinsip-prinsip itu sendiri. Menurut pandangan Dewey cit. Nur (2008), sekolah seharusnya mencerminkan masyarakat yang lebih besar dan kelas seharusnya menjadi laboratorium untuk penyelidikan kehidupan nyata dan pemecahan masalah.

Piaget cit. Suparno (2007) meneliti cara siswa membangun pengetahuan kognitifnya. Siswa akan membentuk skema, mengembangkan skema, dan mengubah skema. Siswa sendiri akan mengkonstruksi pengetahuan dari interaksi dengan pengalaman dan objek yang dihadapi. Dalam pembelajaran Fisika, siswa diberikan kebebasan untuk mempelajari sendiri. Fisika 
merupakan pengetahuan fisis (Piaget cit. Suparno, 2007). Hal ini yang mendasari pentingnya penggunaan metode inkuiri dalam pembelajaran Fisika yang memberi kesempatan siswa untuk mengamati, mengumpulkan data, menganalisis data, dan menyimpulkan.

Sementara itu, dalam realitas pendidikan, masih banyak guru yang menggunakan bahan ajar konvensional. Bahan ajar konvensional yaitu bahan ajar yang langsung beli, langsung pakai, instant, serta tanpa upaya menyiapkan, merencanakan, dan menyusunnya sendiri (Prastowo, 2011). Dengan demikian, sangat dimungkinkan jika bahan ajar yang dipakai kurang sesuai dengan kebutuhan peserta didik. Yoda, et al. (2011) menemukan bahwa tidak ada guru atau siswa yang menggunakan modul dalam pembelajaran di Kabupaten Buleleng. Oleh sebab itu, dikembangkan modul pembelajaran untuk meningkatkan hasil belajar penjasorkes dan kecerdasan kinestetik siswa sekolah dasar.

Pengemasan bahan ajar Fisika selama ini masih bersifat linier, yaitu bahan ajar hanya menyajikan konsep dan prinsip, contoh-contoh soal dan pemecahannya, dan latihan soal. Bahan ajar kurang dikaitkan dengan masalah-masalah nyata di sekitar kehidupan siswa seperti masalah krisis energi, efek rumah kaca, masalah yang ditimbulkan oleh petir, masalah kebakaran gedung akibat konsleting, masalah saluran listrik tegangan tinggi (sutet), dan sebagainya. Menurut Liu cit. Sujanem (2009), pengemasan bahan ajar linier ini kurang memberi peluang pada siswa untuk mengembangkan keterampilan dalam merumuskan masalah, memecahkan masalah, merefleksikan belajarnya, dan mengembangkan pemahaman. Padahal, pembelajaran yang menarik, efektif, dan efisien membutuhkan bahan ajar yang lebih menarik daripada bahan ajar konvensional.

Seperti halnya dalam pemilihan bahan ajar yang lebih memilih bahan ajar yang instan, masyarakat Indonesia pun memiliki pola pikir yang instan. Karena pola pikir instan, sebagian besar masyarakat Indonesia lebih mementingkan produk daripada proses. Hal ini menyebabkan masyarakat Indonesia mudah frustasi dan stress. Tidak jarang berita di media massa tentang kasus bunuh diri maupun orang yang stress dan putus asa dengan keadaan yang dihadapinya.
Orang tidak akan stress atau bahkan bunuh diri apabila bisa menghadapi dan menyelesaikan permasalahan yang dialaminya.

Kondisi tersebut menandakan bahwa dalam proses pendidikan di Indonesia, siswa kurang dilatih dalam memecahkan masalah. Karena belum terbiasa memecakan permasalahan, maka kemampuan memecahkan masalah siswa di Indonesia masih lemah. Berdasarkan kondisi tersebut, maka sejak dini siswa perlu dibiasakan memecahkan permasalahan. Agar siswa bisa belajar tentang pikiran mereka sendiri, para kognitivis mengatakan bahwa cara terbaiknya adalah melalui pembelajaran berdasarkan masalah. Melalui pembelajaran berdasarkan masalah yang memberikan siswa masalah dalam dunia nyata, siswa dapat menyelesaikan permasalahan melalui proses terstruktur. Pembelajaran berdasarkan masalah atau lebih dikenal dengan PBL (Problem Based Learning) merupakan pembelajaran yang dirancang untuk membantu siswa: (1) mengembangkan keterampilan berpikir, pemecahan masalah, dan intelektual; (2) belajar peran-peran orang dewasa dengan menghayati peran-peran itu melalui situasisituasi nyata atau yang disimulasikan; dan (3) mengembangkan keterampilan-keterampilan untuk pembelajaran mandiri (Nur, 2008).

Uraian di atas menunjukkan bahwa dalam pembelajaran Fisika untuk siswa CIBI, diperlukan bahan ajar Fisika yang konseptual dan kontekstual dalam lingkungan PBL. PBL merupakan pembelajaran yang menyajikan masalah sebagai stimulus untuk belajar. Masalah yang disajikan sangat kompleks dan terstruktur serta berhubungan dengan dunia siswa (Nur, 2008).

Penelitian Majid, et al. (2009) dalam serangkaian kegiatan Math and Science Camp di Malaysia yang membelajarkan kemampuan memecahkan masalah pada siswa CIBI menunjukkan bahwa siswa CIBI lebih efektif dalam mengembangkan kemampuan pemecahan masalahnya melalui metode PBL. Tan, et al. (2009) pun menyimpulkan bahwa efektivitas PBL dapat mengembangkan kreativitas siswa. Oleh sebab itu, modul Fisika untuk siswa CIBI dikembangkan berdasarkan model PBL.

Suardana (2006) telah mengembangkan modul menggunakan strategi pembelajaran 
berbasis masalah untuk meningkatkan kualitas proses dan hasil belajar mahasiswa pada perkuliahan Kimia Fisika I. Hasil penelitian menunjukkan bahwa penerapan pembelajaran berbasis masalah dapat meningkatkan kemampuan mahasiswa melakukan pemecahan masalah, meningkatkan aktivitas mahasiswa dalam pembelajaran, dan meningkatkan hasil belajar mahasiswa. Sebagian besar mahasiswa memberikan respon positif dan berharap agar pembelajaran berbasis masalah dengan pendekatan kooperatif berbasis modul dapat dilanjutkan dan dikembangkan pada pembelajaran Kimia Fisika.

Hasil penelitian Sujanem, et al. (2009) menunjukkan bahwa modul Fisika SMA sebaiknya dikembangkan secara eksplisit memuat materi pembelajaran yang kontekstual. Pembelajaran Fisika di SMA sebaiknya dilakukan dengan model pembelajaran berbasis masalah. Hasil pengujian yang dilakukan menunjukkan bahwa modul Fisika yang dikembangkan efektif digunakan sebagai fasilitas belajar dalam pembelajaran Fisika. Kampen, et al. (2012) mengajar menggunakan modul tunggal Fisika melalui PBL dalam kurikulum perkuliahan. Pembelajaran menggunakan modul tunggal berbasis PBL tersebut efektif dalam meningkatkan motivasi belajar mahasiswa sehingga dapat menggantikan posisi pembelajaran berbasis ceramah.

Pembelajaran konstruktivisme dapat memberikan efek kepada siswa CIBI di sekolah menengah dalam kelas sains. Singh (2013) menemukan bahwa program pembelajaran konstruktivisme berharga bagi siswa advance dan siswa CIBI. Program ekstrakurikuler sains juga berharga bagi guru yang membentuk kelompok sebaya dengan komunikasi dan sumber daya yang mendukungnya. Studi kuasieksperimental dari modul jangka pendek berbasis web PBL, studi mandiri, dan kombinasi keduanya oleh Shen, et al. (2007) menunjukkan bahwa desain yang signifikan ialah pembelajaran pedagogi berbasis web PBL untuk modul jangka pendek pada mahasiswa kejuruan di Taiwan.

Berdasarkan uraian tersebut, perlu dikembangkan modul pembelajaran Fisika untuk siswa CIBI berbasis Problem Based Learning (PBL) dan diuji kelayakannya. Tujuan penelitian ini ialah untuk mengembangkan modul Fisika berbasis PBL dan mendeskripsikan kelayakannya, mendeskripsikan respon siswa CIBI terhadap penggunaan modul Fisika berbasis PBL, serta mendeskripsikan efektivitas penggunaan modul Fisika berbasis PBL untuk siswa CIBI.

\section{Metode Penelitian}

Penelitian awal untuk menganalisis kebutuhan siswa dan guru dilaksanakan pada bulan Mei 2012 hingga September 2012. Penelitian pengembangan modul dilaksanakan sejak bulan Oktober 2012 hingga Juni 2013. Penelitian dilaksanakan di lingkungan Universitas Sebelas Maret Surakarta dan MA Unggulan Amanatul Ummah Program Akselerasi.

Penelitian ini merupakan penelitian pengembangan menggunakan modifikasi model 4-D dari Thiagarajan, et al. (1974) yang terdiri dari Define, Design, Develop, dan Disseminate. Pengembangan modul Fisika berbasis PBL dilaksanakan sampai tahap Develop.

Penentuan sampel untuk analisis kebutuhan menggunakan teknik purposive sampling. Penentuan kelas yang digunakan untuk uji coba penggunaan modul Fisika berbasis PBL menggunakan teknik purposive sampling, tetapi penentuan kelas kontrol dan eksperimen dilakukan secara random. Penentuan efektivitas penggunaan modul menggunakan posttest-only control group design.

Instrumen penelitian yang digunakan berupa lembar telaah modul, lembar validasi modul, lembar validasi instrumen penelitian, lembar angket, lembar observasi, lembar posttest, lembar pedoman wawancara, dan peneliti sebagai instrumen penelitian.

Lembar telaah modul digunakan untuk menganalisis kelemahan modul yang dikembangkan dan digunakan sebagai dasar perbaikan modul. Lembar validasi modul digunakan untuk mengetahui tingkat kelayakan modul dari segi isi, bahasa, dan grafis. Lembar validasi instrumen penelitian digunakan untuk memperoleh validitas isi terhadap instrumen yang digunakan untuk pengujian efektivitas penggunaan modul. Lembar angket digunakan 
untuk mengetahui respon siswa terhadap penggunaan modul Fisika berbasis PBL, lembar observasi digunakan untuk mengetahui nilai afektif dan psikomotor siswa selama pembelajaran. Lembar tes digunakan untuk mengukur hasil belajar kognitif siswa. Lembar pedoman wawancara digunakan untuk penelitian mendalam terkait analisis kebutuhan dan data yang mendalam untuk mendukung data yang telah diperoleh menggunakan teknik lainnya. Peneliti sebagai instrumen penelitian dalam menentukan arah penelitian saat melakukan analisis kebutuhan dan penentuan sampel.

Kelayakan modul Fisika berbasis PBL untuk siswa CIBI dideskripsikan berdasarkan hasil telaah dan validasi yang telah dilakukan. Selain itu didukung dengan hasil respon dan efektivitas penggunaannya. Respon siswa terhadap penggunaan modul Fisika berbasis PBL dideskripsikan berdasarkan hasil analisis angket respon siswa. Penentuan efektivitas penggunaan modul Fisika berbasis PBL menggunakan analisis statistik berupa t-test independent sample untuk data kognitif dan afektif, sedangkan untuk data psikomotor menggunakan uji Mann-Whitney $U$.

\section{Hasil Penelitian dan Pembahasan}

Hasil penelitian pendahuluan yang dilakukan ke pengelola dan guru, diperoleh informasi bahwa pelaksanaan pembelajaran kelas akselerasi di MA Unggulan Amanatul Ummah menggunakan sistem unggulan yang disebut dauroh. Sistem dauroh sangat bagus untuk perkembangan kognitif produk siswa dalam mengerjakan soal-soal tes. Namun, beberapa siswa mengalami kesulitan dalam menganalisis soal karena pembelajaran kurang konstekstual. Pembelajaran masih menggunakan sistem ceramah. Kemampuan kognitif produk siswa terasah dari kegiatan latihan-latihan soal yang diadakan di kelas formal maupun di kelas dauroh. Namun, keterampilan kognitif proses dan psikomotor siswa dalam pembelajaran sains masih belum terukur melalui pembelajaran tersebut. Sikap afektif dalam keterampilan proses di laboratorium pun belum bisa terukur. Oleh sebab itu, perlu adanya pembaharuan model pembelajaran di kelas akselerasi MA
Unggulan Amanatul Ummah. Dalam penelitian ini, model pembelajaran yang digunakan adalah PBL sesuai dengan anjuran Direktorat Pembinaan Sekolah Luar Biasa (2009).

Hasil penelitian pendahuluan lebih lanjut, pada tahun 2012 siswa menggunakan buku ajar dari penerbit yang menurut siswa kurang menarik karena siswa kesulitan dalam memahami bahasa dalam buku. Selain itu, tampilan buku kurang kontekstual. Solusi yang dilakukan guru dan pengelola saat itu adalah dengan mengganti buku ajar lain, yaitu dengan memilih pengarang buku berbeda pada penerbit yang sama. Hal ini cukup membantu perubahan siswa. Namun untuk pembelajaran yang konstekstual, buku ajar yang digunakan di sekolah masih kurang mendukung dalam kegiatan laboratorium sekolah. Oleh sebab itu, diperlukan alternatif sumber belajar lain yang bisa mendukung belajar mandiri siswa melalui pembelajaran konstruktivistik. Untuk menjawab permasalahan tersebut, maka dikembangkan modul Fisika berbasis PBL pada materi Fluida. Materi Fluida dipilih karena sesuai dengan model pembelajaran yang digunakan serta aplikasinya dekat dengan kehidupan sehari-hari.

Hasil studi pendahuluan yang lainnya adalah siswa dapat mengikuti instruksi kompleks yang diberikan oleh tutor atau guru dalam kegiatan belajar. Siswa pun dapat menganalisis suatu permasalahan saat diberi fenomena. Siswa suka berhipotesis. Namun, beberapa siswa mengaku tidak dapat menguji kebenaran hipotesisnya karena pembelajaran kurang mendukung untuk menguji hipotesis yang dimilikinya. Siswa akselerasi mampu berpikir abstrak, maka untuk mempelajari sesuatu yang abstrak tidak mengalami kesulitan yang berarti. Namun, pengalaman pembelajaran konstruktivis yang diharapkan siswa perlu diwujudkan dalam sumber belajarnya.

Hasil wawancara dengan siswa menunjukkan bahwa siswa setuju jika ada modul pembelajaran Fisika. Siswa menginginkan modul yang komunikatif, singkat, bahasa tidak terlalu bertele-tele, ada gambargambar untuk memperjelas materi agar tidak jenuh, ada latihan soal, dan ada pembahasannya. Analisis tugas dilakukan dengan menganalisis kurikulum yang disesuaikan tahap berpikir tingkat tinggi sesuai dengan karakter 
belajar siswa CIBI. Materi yang dipilih ialah tentang Fluida karena materi Fluida lebih dekat dengan kehidupan siswa dan dapat dikemas dalam pembelajaran konstekstual. Selanjutnya dianalisis kegiatan belajar yang dilakukan siswa dalam menggunakan modul Fisika berbasis PBL yang dikembangkan. Konsep-konsep materi yang perlu diajarkan dikemas dalam bentuk peta konsep. Hasil analisis siswa dan analisis tugas tersebut digunakan untuk merumuskan tujuan pembelajaran.

$$
\text { Rumusan tujuan pembelajaran }
$$

berdasarkan hasil analisis dibuat sesuai indikator yang telah disesuaikan dengan tahap berpikir siswa CIBI. Kemudian disusun silabus dan Rencana Pelaksanaan Pembelajaran (RPP) berbasis PBL sebagai dasar pembuatan modul Fisika berbasis PBL untuk siswa CIBI. Selain itu, penilaian siswa disusun dalam bentuk kisikisi soal untuk mengukur hasil belajar siswa CIBI setelah menggunakan modul Fisika berbasis PBL yang dikembangkan.

Penyusunan materi dilakukan dengan menelaah materi Fisika Dasar tingkat Universitas agar diperoleh kedalaman materi yang lebih luas daripada materi di kelas reguler. Setelah disusun materi, dibuat lay out modul. Selanjutnya, dibuat desain kegiatan belajar dalam modul yang sesuai dengan sintaks PBL.

$$
\text { Adapun sintaks PBL yaitu: }
$$

Mengorientasikan siswa kepada masalah, (2) Mengorganisasikan siswa untuk belajar, (3) Membantu penyelidikan mandiri dan kelompok, (4) Mengembangkan dan menyajikan hasil karya serta memamerkannya, dan (5) Menganalisis dan mengevaluasi proses pemecahan masalah (Nur, 2008). Berdasarkan sintaks tersebut, dibuat desain kegiatan belajar dalam modul yang terdiri dari: (1) Motivasi Awal, (2) Pengantar Kegiatan, (3) Laboratorium Fisika, (4) Ayoo Pahami Konsep...!, (5) Aplikasi Matematika dan Aplikasi Konsep, serta (6) Tes Formatif.

Modul dibuat sesuai desain yang telah dibuat dengan dilengkapi petunjuk penggunaan modul serta arahan di tiap akhir kegiatan belajar. Modul terdiri dari 7 kegiatan belajar yang terdiri dari Tekanan dan Prinsip Pascal, Pengaruh Kedalaman terhadap Tekanan Hidrostatis, Prinsip Archimedes dan Aplikasinya, Tegangan Permukaan dan Kapilaritas, Aliran Fluida dan Kontinuitas, Persamaan Bernoulli dan
Aplikasinya, serta Viskositas dan Hukum Poiseuille.

Majid, et al. (2011) menyatakan bahwa bahan ajar untuk belajar siswa berbakat harus memperhatikan kreativitas dan kemampuan berpikir siswa. Oleh sebab itu, pengembangan modul Fisika yang sesuai siswa CIBI adalah modul Fisika yang memuat pembelajaran konstruktivis yang dapat memunculkan kreativitas siswa melalui tantangan-tantangan dalam bereksperimen. Ranah kognitif yang digunakan dikembangkan hingga tahap C-6, sedangkan penilaian aspek afektif siswa dikembangkan hingga aspek characterize.

Modul yang telah dibuat berdasarkan desain awal kemudian ditelaah dan divalidasi oleh ahli bahasa dan grafis, serta ahli materi. Setelah memperoleh masukan, modul direvisi. Selanjutnya dilakukan telaah dan validasi tahap kedua oleh dosen Fisika. Saran yang diperoleh digunakan untuk revisi lebih lanjut. Setelah itu dilakukan telaah dan validasi oleh rekan sejawat, yaitu guru Fisika di program akselerasi MA U Amanatul Ummah. Hasil telaah digunakan untuk merevisi lebih lanjut.

Tabel 1: Hasil Validasi Tahap Pertama

\begin{tabular}{clcc}
\hline No & Elemen yang Divalidasi & Rata-Rata & Kategori \\
\hline 1. & Kelayakan Isi & 3,17 & Baik \\
2. & Penyajian Materi & 3,44 & Baik \\
3. & Bahasa dan Keterbacaan & 3,08 & Baik \\
4. & Kegrafisan & 3,05 & Baik \\
5. & Aspek PBL dalam modul & 3,40 & Baik \\
\hline \multicolumn{2}{c}{ Nilai Rata-Rata Kelayakan } & 3,22 & Baik \\
\hline
\end{tabular}

Tabel 1 menunjukkan hasil validasi tahap pertama. Modul yang dikembangkan telah memenuhi kategori baik. Namun masih terdapat kelemahan pada aspek bahasa dan keterbacaan serta pada aspek kegrafisan.

Tabel 2: Hasil Validasi Tahap Kedua

\begin{tabular}{clcc}
\hline No & Elemen yang Divalidasi & Rata-Rata & Kategori \\
\hline 1. & Kelayakan Isi & 3,44 & Baik \\
2. & Penyajian Materi & 3,63 & Baik \\
3. & Bahasa dan Keterbacaan & 3,33 & Baik \\
4. & Kegrafisan & 3,43 & Baik \\
5. & Aspek PBL dalam modul & 3,37 & Baik \\
\hline \multicolumn{2}{c}{ Nilai Rata-Rata Kelayakan } & 3,45 & Baik \\
\hline
\end{tabular}

Tabel 2 menunjukkan hasil validasi tahap kedua. Setelah dilakukan revisi pada tahap pertama, terjadi peningkatan nilai rata-rata kelayakan modul Fisika berbasis PBL yang dikembangkan. Untuk mengetahui kesesuaian 
modul dengan karakter siswa, validasi selanjutnya dilakukan oleh guru Fisika program akselerasi yang dianggap lebih mengetahui karakter siswa.

Tabel 3: Hasil Validasi Rekan Sejawat (Tahap Ketiga)

\begin{tabular}{clcc}
\hline No & Elemen yang Divalidasi & Rata-Rata & Kategori \\
\hline 1. & Kelayakan Isi & 3,83 & Baik \\
2. & Penyajian Materi & 3,81 & Baik \\
3. & Bahasa dan Keterbacaan & 3,42 & Baik \\
4. & Kegrafisan & 3,50 & Baik \\
5. & Aspek PBL dalam modul & 3,50 & Baik \\
\hline \multicolumn{2}{c}{ Nilai Rata-Rata Kelayakan } & 3,61 & Baik \\
\hline
\end{tabular}

Tabel 3 menunjukkan hasil validasi tahap ketiga. Hasil validasi modul Fisika berbasis PBL untuk siswa CIBI menunjukkan bahwa modul layak digunakan dengan kategori baik. Selanjutnya, modul diuji coba penggunaannya oleh siswa kelas XI semester 2 MA Unggulan Amanatul Ummah Program Akselerasi. Setelah siswa belajar materi Fluida dalam lingkungan PBL dengan media yang berbeda, siswa dites dengan soal posttest. Kelas yang menggunakan modul Fisika berbasis PBL diminta memberikan tanggapan tentang penggunaan modul melalui angket respon siswa.

Hasil analisis angket tertutup terhadap respon siswa menunjukkan bahwa rata-rata respon ketertarikan siswa berada pada daerah 93,75\% untuk isi modul, $92,71 \%$ untuk model pembelajaran, serta $91,67 \%$ untuk modul secara keseluruhan. Artinya, siswa sangat tertarik terhadap isi modul, model pembelajaran, dan modul Fisika berbasis PBL secara keseluruhan. Sedangkan rata-rata kemudahan siswa dalam mempelajari modul ialah $88,54 \%$ untuk bahasa dalam modul, $89,56 \%$ untuk perunjuk dalam modul, 83,33\% untuk isi modul, dan 83,33\% untuk kegiatan laboratorium Fisika dalam modul. Artinya, modul sangat mudah untuk dipahami oleh siswa CIBI. Sedangkan pada angket respon terbuka, 100\% siswa menyatakan dapat memahami bahasa yang digunakan dalam modul dan $100 \%$ siswa tertarik pada penampilan modul.

Siswa secara umum tertarik menggunakan modul Fisika berbasis PBL. Siswa pun dapat memahami bahasa, petunjuk, isi, dan kegiatan laboratorium Fisika dalam modul dengan mudah. Setelah menggunakan modul Fisika berbasis PBL, siswa berminat untuk mempelajari Fisika menggunakan model PBL yang pokok bahasannya dihubungkan dengan fenomena dalam kehidupan sehari-hari. Siswa pun merasa mudah dalam mengerjakan butir tes setelah belajar menggunakan modul Fisika berbasis PBL. Hasil wawancara dengan beberapa siswa yang menggunakan modul Fisika berbasis PBL menunjukkan respon positif terhadap isi materi pada modul. Demikian pula terhadap penggunaan bahasa dan kegrafisan pada modul.

Data hasil belajar siswa berupa data kognitif, afektif, dan psikomotor. Rata-rata nilai kognitif siswa ditunjukkan oleh nilai posttest yang digambarkan oleh Grafik 1. Rata-rata nilai afektif siswa ditunjukkan oleh Grafik 2, dan rata-rata nilai psikomotor siswa ditunjukkan oleh Grafik 3.
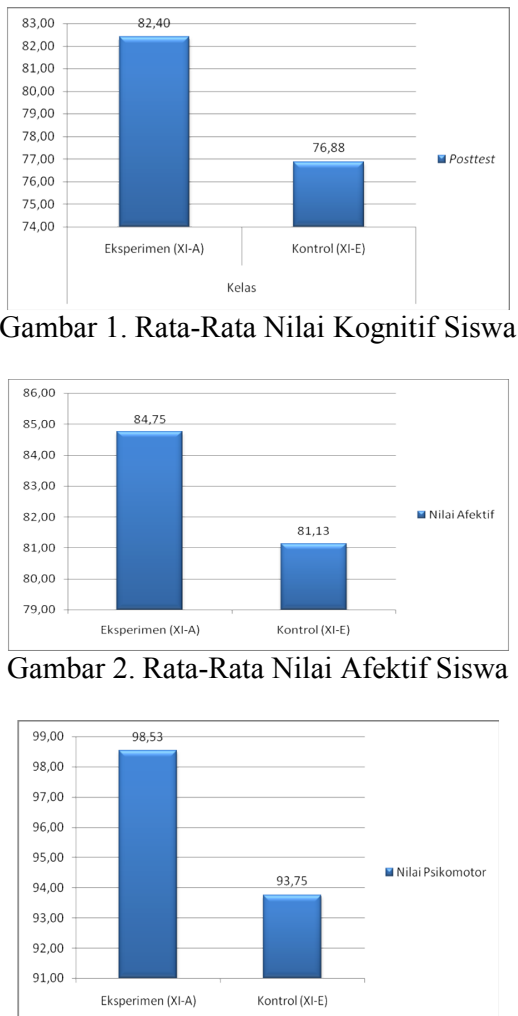

Gambar 3. Rata-Rata Nilai Psikomotor Siswa

Data hasil belajar kognitif dan afektif terdistribusi normal dan homogen. Oleh sebab itu, uji hipotesis efektivitas penggunaan modul menggunakan t-test independent sample. Sedangkan data hasil belajar psikomotor tidak normal dan tidak homogen. Oleh sebab itu, uji hipotesis efektivitas penggunaan modul 
menggunakan uji Mann-Whitney U. Pengolahan data statistik menggunakan bantuan software PASW Statistics 18.

Tabel 4: Hasil t-test independent sample dua pihak

\begin{tabular}{lccc} 
& \multicolumn{3}{c}{ Uji t untuk kesamaan rata-rata } \\
\cline { 2 - 4 } & $\mathbf{t}$ & $\mathbf{d f}$ & Sig. (2-tailed) \\
\hline Afektif & 2,202 & 42 &, 033 \\
Pos_Tes & 2,435 & 42 &, 019 \\
\hline
\end{tabular}

Tabel 4 menunjukkan bahwa signifikansi data hasil belajar afektif sebesar 0,033<0,05. Artinya, ada perbedaan hasil belajar antara siswa CIBI yang menggunakan modul Fisika berbasis PBL dengan siswa CIBI yang menggunakan buku cetak di sekolah. Berdasarkan rata-rata hasil belajar afektif dapat diketahui bahwa hasil belajar afektif kelas eksperimen lebih baik daripada kelas kontrol. Dengan demikian, dapat disimpulkan bahwa hasil belajar afektif siswa yang menggunakan modul Fisika berbasis PBL lebih baik dari pada siswa yang menggunakan buku di sekolah dan perbedaannya signifikan.

Sedangkan hasil belajar kognitif yang ditunjukkan oleh posttest memiliki signifikansi sebesar $0,019<0,05$. Artinya, ada perbedaan hasil belajar kognitif siswa CIBI yang menggunakan modul Fisika berbasis PBL dengan siswa CIBI yang menggunakan buku cetak di sekolah. Berdasarkan rata-rata hasil belajar kognitif, dapat diketahui bahwa hasil belajar kognitif kelas eksperimen lebih baik daripada kelas kontrol. Dengan demikian, dapat disimpulkan bahwa hasil belajar kognitif siswa yang menggunakan modul Fisika berbasis PBL lebih baik daripada siswa yang menggunakan buku cetak di sekolah dan perbedaannya signifikan.

\begin{tabular}{lr} 
Tabel 5: Hasil uji Mann-Whitney $U$ dua pihak \\
\hline & \multicolumn{1}{c}{ Psikomotor } \\
\hline Mann-Whitney U & 153,500 \\
Wilcoxon W & 363,500 \\
Z & $-2,317$ \\
Asymp. Sig. (2-tailed) &, 021 \\
\hline
\end{tabular}

Tabel 5 menunjukkan bahwa signifikansi data hasil belajar psikomotor sebesar 0,021 < 0,05 . Artinya, ada perbedaan hasil belajar psikomotor antara siswa yang menggunakan modul Fisika berbasis PBL dengan siswa yang menggunakan buku cetak di sekolah. Berdasarkan nilai rata-rata hasil belajar psikomotor dapat diketahui bahwa hasil belajar psikomotor siswa kelas eksperimen lebih baik daripada siswa kelas kontrol. Dengan demikian dapat disimpulkan bahwa hasil belajar psikomotor siswa yang menggunakan modul Fisika berbasis PBL lebih baik daripada siswa yang menggunakan buku cetak di sekolah dan perbedaannya signifikan.

Berdasarkan analisis statistik terhadap hasil belajar Fisika menggunakan media berbeda dalam lingkungan PBL, dapat disimpulkan bahwa penggunaan modul Fisika berbasis PBL dapat meningkatkan hasil belajar kognitif, afektif, dan psikomotor siswa CIBI. Temuan ini sejalan dengan temuan Suardana (2006) yang mengemukakan bahwa penerapan pembelajaran berbasis masalah dapat meningkatkan kemampuan mahasiswa dalam memecahkan masalah, meningkatkan aktivitas mahasiswa dalam pembelajaran, dan meningkatkan hasil belajar mahasiswa.

Sebagian besar mahasiswa dalam penelitian Suardana (2006) memberikan respon positif dan berharap agar pembelajaran berbasis masalah dengan pendekatan kooperatif berbantuan modul dapat dilanjutkan dan dikembangkan dalam pembelajaran Kimia Fisika. Demikian juga dengan hasil penelitian ini, siswa CIBI memberikan respon positif terhadap penggunaan modul Fisika berbasis PBL. Berdasarkan hasil wawancara, siswa berharap agar pembelajaran Fisika berbasis PBL menggunakan modul dapat dilanjutkan pada materi Fisika lainnya. Selain itu, hasil angket menunjukkan bahwa siswa CIBI sangat berminat dengan pembelajaran PBL yang bersifat kontekstual.

Singh (2013) menemukan bahwa program belajar yang bersifat konstruktivisme berharga bagi siswa advance maupun siswa CIBI. Kegiatan belajar konstruktivis dalam penelitian ini berupa kegiatan belajar Fisika dalam lingkungan PBL. Pembelajaran PBL menggunakan modul menjadi berharga bagi siswa saat siswa menunjukkan respon sangat positif terhadap penggunaan modul Fisika berbasis PBL untuk siswa CIBI.

Hasil penelitian Watters \& Diezmann (2003) tentang siswa CIBI dalam pembelajaran sains menyatakan bahwa praktik sains berupa pemecahan masalah otentik dapat menjawab kebutuhan intelektual siswa CIBI. Dalam 
penelitian ini, terpenuhinya kebutuhan intelektual siswa dapat diketahui melalui respon positif yang diberikan siswa setelah belajar menggunakan modul Fisika berbasis PBL. Selain itu, perbedaan hasil belajar yang signifikan setelah menggunakan modul juga menunjukkan bahwa siswa dapat mengkonstruksi pengetahuan mereka melalui kegiatan PBL dan dapat menyelesaikan permasalahan yang disajikan saat posttest.

Modul Fisika berbasis PBL dapat menyiapkan masalah-masalah nyata yang dikemas dalam bentuk modul yang dapat digunakan belajar mandiri siswa. Materi ajar dalam modul memberi peluang bagi siswa CIBI dalam mengkonstruksi makna melalui kegiatan Laboratorium Fisika, Ayoo...Pahami Konsep...! dan Aplikasi Konsep yang dapat memfasilitasi siswa dalam memahami konsep dan meningkatkan hasil belajar. Siswa CIBI memiliki kecepatan belajar yang berbeda dengan siswa reguler. Oleh sebab itu, fleksibilitas waktu merupakan ciri utama modul untuk siswa CIBI. Tiap kegiatan belajar diberi saran waktu untuk mempelajari modul tersebut, namun penggunaan waktu untuk belajar tidak terlalu ketat. Batasan maksimum penyelesaian kegiatan pembelajaran diberikan, namun siswa dapat memilih topik yang lebih dahulu dipelajari sesuai dengan minatnya. Untuk mengoptimalkan hasil belajar Fisika pada kelas akselerasi, sebaiknya digunakan modul Fisika berbasis PBL.

\section{Kesimpulan dan Rekomendasi}

Kesimpulan yang diperoleh dari hasil penelitian ini adalah: (1) modul Fisika berbasis PBL untuk Siswa CIBI telah layak digunakan dengan kategori baik. Kelayakan dapat dilihat dari hasil validasi ahli $(3,22)$ dan dosen Fisika $(3,45)$ yang secara keseluruhan komponen yang ada di dalam modul termasuk kategori baik. Berdasarkan angket validasi guru Fisika di kelas akselerasi, diperoleh hasil validasi yang menyatakan kategori baik $(3,61)$. Selain itu, berdasarkan angket respon siswa dan wawancara beberapa siswa dapat diketahui bahwa modul yang dikembangkan sesuai dengan karakteristik belajar siswa CIBI; (2) siswa CIBI di MA U Amanatul Ummah Program Akselerasi memberi respon sangat positif terhadap modul Fisika berbasis PBL; (3) secara statistik, pada interval kepercayaan 95\% (taraf signifikansi 0,05), dapat disimpulkan bahwa penggunaan modul Fisika berbasis PBL lebih efektif untuk meningkatkan hasil belajar kognitif, afektif, dan psikomotor siswa CIBI daripada penggunaan buku cetak di sekolah.

Rekomendasi untuk penelitian selanjutnya adalah agar dikembangkan penelitian serupa menggunakan materi berbeda yang sesuai dengan model pembelajaran PBL. Penelitian serupa juga dapat dikembangkan untuk model pembelajaran konstruktivis lain yang sesuai dengan karakteristik siswa CIBI, misalnya SAVI (Somatic Auditory Visual Intelegence), Quantum Learning, CTL (Contextual Teaching and Learning), dan sebagainya.

\section{Daftar Pustaka}

Ahmadi, I.K., Setyono, H.A., \& Amri, S. (2011). Pembelajaran Akselerasi: Analisis teori dan Praktik serta Pengaruhnya Terhadap Mekanisme Pembelajaran dalam Kelas Akselerasi. Jakarta: Prestasi Pustaka Publisher.

Alias, N. \& Siraj S. (2012). Design and Development of Physics Module Based on Learning Style and Appropiate Technology by Employing Isman Instructional Design Model. The Turkish Online Journal of Educational Technology, 11 (4).

Dahar, R.W. (1989). Teori-Teori Belajar. Jakarta: Erlangga.

Direktorat Pembinaan SLB, Dirjen Manajemen Dikdasmen, Depdiknas. (2009). Pedoman Penyelenggaraan Pendidikan untuk Peserta Didik Cerdas Istimewa. Jakarta: Depdiknas.

Kampen, P., Banahan C., Kelly, M., McLoughlin E., \& O'Leary E. (2004). Teaching a single physics module through Problem Based Learning in a lecture-based curriculum. American Assosiation of Physics Teachers [DOI: 10.1119/1.1645280]

Majid, R.A., Yassin, S.F.M., Abdullah, N.G., Ramli, R., Hassan, S.A., Latiff, M.N., \& Ishak, N.M. (2011). Project-Based Learning for Academically Talented Students at a Math and Science Camp. World Applied Sciences Journal, 14: 01-05.

Nur, M. (2008). Model Pembelajaran Berdasarkan Masalah. Surabaya: Pusat Sains dan Matematika Sekolah Universitas Negeri Surabaya. 
Prastowo, A. (2011). Panduan Kreatif Membuat Bahan Ajar Inovatif: Menciptakan Metode Pembelajaran yang Menarik dan Menyenangkan. Jogjakarta: DIVA Press.

Shen, P.D., Lee, T.H., \& Tsai, C.W. (2007). Applying Web-Enabled Problem-Based Learning and Self-Regulated Learning to Enhance Computing Skills of Taiwan's Vocational Students: a Quasi-Experimental Study of a Short-Term Module. Electronic Journal of e-Learning, 5 (2): 147-156.

Singh, A. (2013). Constructivism and The Effect of Teaching Gifted Middle Schools Science Students. European International Journal of Science and Technology, 2 (1).

Suardana, I.N. (2006). Penerapan Strategi Pembelajaran Berbasis Masalah dengan Pendekatan Kooperatif Berbantuan Modul untuk Meningkatkan Kualitas Proses dan Hasil Belajar Mahasiswa pada Perkuliahan Kimia Fisika I. Jurnal Pendidikan dan Pengajaran IKIP Negeri Singaraja, 4: 751-764.

Sujanem, R., Suwindra, I.N.P., Tika, I.K.. (2009). Pengembangan Modul Fisika Kontekstual Interaktif Berbasis Web Untuk Siswa Kelas I SMA. Jurnal Pendidikan dan Pengajaran, 42 (2): $97-104$

Suparno, P. (2007). Metode Penelitian Pendidikan Fisika. Yogyakarta: Penerbit Universitas Sanata Dharma.

Tan, O. (2009). Problem Based Learning and Creativity. Singapore: Cengange Learning Asia Pte Ltd.

Thiagarajan, S., Semmel, D.S., \& Semmel, M. L. (1974). Instructional Development for Training Teachers of Exceptional Children, A Source Book. Bloomington: A Joint Publication of Leadershing Training Institute/Special Education, University of Minnesota; The Center for Innovation in Teaching the Handicapped (CITH), Indiana University; The Council for Exceptional Children (CEC), and The Teacher Education Division of CEC.

Thomson, M. (2006). Supporting Gifted \& Talented Pupils in the Secondary School. London: Paul Chapman Publishing.

Watters, J.J. \& Diezmann, C.M. (2003). The Gifted Student in Sciences: Fulfilling Potential. Australian Science Teachers Journal, 49 (3): 46-53.

Yoda, I.K., Kanca, I.N., \& Wijaya, M.A. (2011). Pengembangan Modul Bermuatan Model Pembelajaran Bandura untuk Meningkatkan Hasil Belajar Penjasorkes dan Kecerdasan Kinestetik Siswa Sekolah Dasar. Jurnal
Penelitian dan Pengembangan Pendidikan, Lembaga Penelitian Undiksha, 5 (3): 341-376. 